\title{
Biochemical and Antimicrobial Characterization of an Underexploited Medicinal Plant - Verbesina encelioides
}

\author{
C.K. Divya Ramakrishnan ${ }^{1 *}$, Dayal Doss ${ }^{2}$ and A. Vijayabharathi ${ }^{3}$ \\ ${ }^{1}$ Department. of Biotechnology, Sri Narayanaguru College, Coimbatore-641 105, \\ Tamil Nadu, India \\ ${ }^{2}$ Department of Plant Biotechnology, GKVK, UAS, Bangalore - 560065, Karnataka, India \\ ${ }^{3}$ Department Genetics and Plant Breeding, University of Agricultural Sciences, \\ Bangalore - 560065, Karnataka, India \\ *Corresponding author
}

\section{A B S T R A C T}

K e y w o r d s
Verbesina
encelioides,
Antimicrobial,
Antifungal,
Biochemical
characterization.
Article Info
Accepted:
26 October 2017
Available Online:
10 December 2017

\section{Introduction}

All organisms have evolved several defense systems in order to protect themselves against bacteria, fungi and viruses. Plants constitute an excellent ecosystem for microorganisms. Microbes interact with plant tissues and cells with different degree of dependence. Plants are the tremendous source for the discovery of new products of medicinal value for new drug development. Many of the drugs sold today are simple synthetic modifications of naturally obtained substances. Much work has been done on ethno-medicinal plants in India. Verbesina encelioides, a member of the Asteraceae (sunflower) family, is an erect annual commonly seen to heights of 1 to 5 feet. Its common names are golden crown beard, crown beard, wild sunflower and yellow top. The native range of Verbesina encelioides is generally considered to be North and South America, specifically 
Mexico and the Southwestern United States of Texas, Arizona Open areas appear to be ideal habitat for the plant (Robbins et al., 1951 and Parker 1972).

United leaves of Verbesina encelioides are toothed or lobed and have two distinct growth patterns like the lower leaves are opposite and triangular, while the upper leaves are alternate and lance shaped. Both upper and lower leaves featured with fine white hairs on the undersides, which are also present on the stem of Verbesina encelioides, which grows from a taproot system.

Flower heads are found on elongated stalks, and resemble small flowers, 1-2 inches in length. Flower heads can either be solitary, or in clusters of up to three heads. Seeds of Verbesina encelioides are greyish-brown, flat and winged along the margins and are considered as drought tolerant plant. This propagates by seeds. The plant demonstrates an efficient ability for both self and cross pollination (Parker, 1972).

Medicinal uses of Verbesina encelioides appear to be limited and not widely documented. However, M. Moore, the Director of the Southwest School of Botanical Medicine refers that the plant is primarily an anti-inflammatory for redness and swelling of the orifices.

The paste is applied directly to hemorrhoids, labial inflammations and sore gums. Earlier medicinal uses are thought to have been practiced by the Indian tribe, utilizing Verbesina encelioides for the treatment of spider bite symptoms. Galegine and ferulic acid have been reported as key phytochemicals, present in this plant.

Galegine, an alkaloid, has both antimicrobial and anti-tumor properties. Ferulic acid has been claimed to reduce the side effects of chemo- and radiotherapy of carcinomas by increasing natural immune defenses. So keeping this in mind, an attempt has been made to study the biochemical, antimicrobial and antifungal characters of the medicinal plant Verbesina encelioides.

\section{Materials and Methods}

\section{Geographical survey of Verbesina encelioides}

The plant material was surveyed in different regions of Eastern dry districts of Karnataka, India. Sample 1 was collected from Marathalli, Bangalore. Sample 2 was collected from Bangarapet Kolar district. Sample 3 was also collected from Thavarekere, Kolar. Sample 4 was collected from Chintamani. Sample 5 was collected from Mulabagal and Sample 6 was also from Kolar-Tavarekere village.

\section{Biochemical analysis}

\section{Preparation of acetone powder}

Five gram of fresh plant leaves were transferred to a blender. Pre-chilled acetone (kept at $-20^{\circ} \mathrm{C}$ ) was added sufficiently to cover the sample and then blended for 2-3 minutes at low speed followed by high speed for 3 to 5 minutes with an intermittent break. Then the mixture was filtered through a Buchner funnel with Whattman Grade 1 filter paper. Finally, the powder was spread on filter paper and air dried and kept at $-20^{\circ} \mathrm{C}$ till further use.

\section{Estimation of total soluble protein content}

$100 \mathrm{mg}$ of acetone powder was extracted with $10 \mathrm{ml}$ of $0.1 \mathrm{M}$ sodium phosphate buffer $(\mathrm{pH}$ 7.0) for one hour on a magnetic stirrer at room temperature. The extract was centrifuged at 10,000 rpm for 20 minutes and the supernatant was used for the estimation of total soluble protein content (Lowry et al., 1951). 


\section{Reagents}

\section{Solution A}

$20 \mathrm{~g}$ of anhydrous sodium carbonate $\left(\mathrm{Na}_{2} \mathrm{CO}_{3} .2 \mathrm{H}_{2} \mathrm{O}\right)$ and $4 \mathrm{~g}$ of sodium hydroxide were dissolved in $1000 \mathrm{ml}$ of distilled water.

\section{Solution B}

$1 \mathrm{ml}$ of $1.35 \%$ sodium potassium tartarate and $0.1 \mathrm{ml}$ of $5.5 \% \mathrm{CuSO}_{4} .5 \mathrm{H}_{2} \mathrm{O}$ solutions were mixed together.

\section{Solution C}

$50 \mathrm{ml}$ of solution A was mixed with $1 \mathrm{ml}$ of solution B just before use.

\section{Folin-Ciocalteau reagent (FCR)}

The commercial FCR was diluted in 1:1 before use.

Standard bovine serum albumin (BSA) solution: A stock BSA solution was prepared containing $2 \mathrm{mg} \mathrm{BSA} / \mathrm{ml}$ in water. This solution was diluted $1: 10$ to obtain $200 \mu \mathrm{g}$ $\mathrm{BSA} / \mathrm{ml}$ of working standard solution.

\section{Estimation}

A known volume of aliquot sample was made up to $1 \mathrm{ml}$ with distilled water. To this, $5 \mathrm{ml}$ of solution $\mathrm{C}$ was added and mixed well. After 10 minutes, $0.5 \mathrm{ml}$ of FCR was added and mixed immediately. The blue colour developed was read at $660 \mathrm{~nm}$ after 30 minutes against a reagent blank in a colorimeter.

\section{Preparation of leaf sample}

The leaf samples collected from plants were dried in oven and then made into fine powder using mortar and pestle. The powdered samples were preserved in butter paper/ polythene cover and used for biochemical analysis.

\section{Estimation of total soluble sugars}

\section{Phenol reagent}

$5 \mathrm{~g}$ of re-distilled phenol is dissolved in $95 \mathrm{ml}$ of distilled water.

\section{Sample extraction}

$100 \mathrm{mg}$ of dry sample was extracted with 10 $\mathrm{ml}$ of $80 \%$ warm ethanol in a pestle and mortar.

Then the extract was centrifuged at 10,000 rpm for ten minutes and the extract was evaporated to dryness in a hot water bath and the residue was dissolved in $5 \mathrm{ml}$ of distilled water. Interfering coloured pigments were removed by using activated charcoal by keeping it overnight.

The extract was centrifuged and clear supernatant was used for the estimation of total sugars (Dubios, 1951).

\section{Estimation}

Known aliquot extracts were made up to $1 \mathrm{ml}$ with distilled water and $0.5 \mathrm{ml}$ of phenol reagent was added and mixed well. $5 \mathrm{ml}$ of 96\% sulphuric acid and placed in a hot water bath at $30^{\circ} \mathrm{C}$ for 20 minutes. Absorbance was read at $490 \mathrm{~nm}$. The amount of total sugars in the sample was estimated by comparing the results with a standard glucose curve.

\section{Estimation of total phenol content}

\section{Reagents: Folin-Ciocalteau reagent}

Commercial grade reagent was diluted 1:1 ratio with distilled water. 


\section{$20 \%$ Sodium carbonate solution}

$20 \mathrm{~g}$ of $\mathrm{Na}_{2} \mathrm{CO}_{3}$ was dissolved in distilled water and made up to $100 \mathrm{ml}$.

\section{Acidified methanol}

$10 \mathrm{ml}$ of hydrochloric acid $(\mathrm{HCl})$ was mixed with $90 \mathrm{ml}$ of methanol.

\section{Standard catechol solution}

A stock catechol solution was prepared containing $1 \mathrm{mg}$ catechol / $\mathrm{ml}$ in water. This solution was diluted 1:10 ratio to obtain 100 $\mu \mathrm{g}$ catechol / $\mathrm{ml}$ of working standard solution.

\section{Sample extraction}

$100 \mathrm{mg}$ of oven-dried powdered sample was extracted in $10 \mathrm{ml}$ of warm $80 \%$ ethanol for 1 hour at room temperature. The extract was centrifuged at $6000 \mathrm{rpm}$ for 15 minutes. The supernatant was evaporated to dryness on a water bath and the residue was dissolved in 5 $\mathrm{ml}$ of water.

The alcohol free extract was used for the estimation of total phenols (Malick and Singh, 1980).

\section{Estimation}

$0.1 \mathrm{ml}$ of aliquot sample was diluted to $3 \mathrm{ml}$ with distilled water and $0.5 \mathrm{ml}$ of FCR was added and mixed thoroughly. Exactly after 3 minutes, $2 \mathrm{ml}$ of $20 \%$ sodium carbonate solution was added and kept in a boiling water bath for one minute.

After cooling under running tap water, the absorbance was read at $650 \mathrm{~nm}$, against the reagent blank in a colorimeter. A standard graph was constructed with catechol as a standard in the range of $20-100 \mu \mathrm{g}$ per gram of sample.

\section{Estimation of total tannin content}

\section{Reagents: Vanillin- $\mathrm{HCl}$ reagent}

$8 \% \mathrm{HCl}$ in methanol and $4 \%$ vanillin in methanol were mixed in equal volumes just before use.

\section{Standard catechin solution}

A stock catechin solution was prepared containing $1 \mathrm{mg}$ catechin $/ \mathrm{ml}$ in methanol. This solution was diluted 1:10 ratio to obtain $100 \mu \mathrm{g}$ catechin / $\mathrm{ml}$ of working standard solution.

\section{Sample extraction}

$100 \mathrm{mg}$ of oven-dried powdered sample was extracted with $5 \mathrm{ml}$ of methanol for 24 hours at room temperature with occasional stirring. The extract was centrifuged at $5000 \mathrm{rpm}$ for 10 minutes. The supernatant was used for the estimation of total tannins (Burns, 1971).

\section{Extraction}

To $1 \mathrm{ml}$ of the aliquot sample, $5 \mathrm{ml}$ of vanillin- $\mathrm{HCl}$ reagent was added and mixed. After incubation for 20 minutes, the absorbance was read at $500 \mathrm{~nm}$ against a reagent blank in a colorimeter.

A standard graph was constructed using catechin as a standard in the range of 0.2-2.0 $\mathrm{mg} / \mathrm{g}$ of oven-dried sample.

\section{Estimation of micronutrients $\mathrm{Fe}, \mathrm{Mg}, \mathrm{Zn}$} and $\mathrm{Cu}$

Powdered leaf sample is pre-digested in concentrated nitric acid, then with di-acid mixture, which gives snow white residue. This is then cooled and volume is made up to $150 \mathrm{ml}$ with distilled water and filtered to remove silica precipitate. The obtained 
supernatant is used to estimate micronutrients by atomic absorption spectrophotometer (Black, 1965).

\section{Electrophoretic characterization of soluble proteins}

\section{Sample preparation}

$100 \mathrm{mg}$ of acetone powder was extracted in $10 \mathrm{ml}$ of $0.1 \mathrm{M}$ sodium phosphate buffer $(\mathrm{pH}$ 7.0) for 1 hour on a magnetic stirrer at room temperature.

The extract was centrifuged at $10,000 \mathrm{rpm}$ for 20 minutes and the supernatant was used for characterization of soluble protein profiles.

\section{SDS-PAGE}

The SDS-PAGE of soluble proteins was performed in a slab gel by preparing $10 \%$ resolving gel and 5\% stacking gel. The method followed was based on the procedure described by Laemmli (1970).

\section{Anti-microbial activity of plant extracts of V. encelioides}

\section{Bioassay for anti-bacterial activity}

\section{Collection of bacterial cultures}

The animal or human pathogens were collected from Ramaiah, Medical Institute, Bangalore, Karnataka. Plant pathogen, which was maintained in the Department of plant pathology, University of Agricultural Sciences (UAS), GKVK, Bangalore.

The animal pathogens (B1 - Staphylococcus aureus, B2 - Pseudomonas aeruginosa, B3 Enterococcus faecalis, B4 - Escherichia coli and B5 - Staphylococcus coagulance) and plant pathogens were used for the zone of inhibition test as follows.

\section{Filter disc}

The filter paper was cut into $1.5 \mathrm{~cm}$ diameter and kept in a bottle and autoclaved at $121^{\circ} \mathrm{C}$ at $15 \mathrm{lbs}$. for 15 minutes. Nutrient agar medium was prepared and autoclaved after the medium was poured into the sterile petri plate. Each plate contains $15-20 \mathrm{ml}$ of media.

\section{Plant extract for zone of inhibition studies}

The selected healthy plant material of $V$. encelioides was thoroughly washed with distilled water. The leaves of the plant were crushed with the help of sterile pestle and mortar and extracts were collected.

The extracts were centrifuged at 2,000 rpm for 10 to 15 minutes. The solid particles that were settled in the bottom and the clear supernatant extracts were collected in a sterile bottle. Then the solution was filtered through Millipore membrane $(0.45 \mu \mathrm{m})$ was stored in sterile bottle at $4^{\circ} \mathrm{C}$ till use.

\section{Zone of inhibition test}

To make a lawn of bacterial cultures a standard spread plate method was followed. Then the sterile filter disc $(1.5 \mathrm{~cm}$ diameter) was taken and immersed in cell free extract of $V$. encelioides and the excess extracts were removed.

Then it was transferred on lawn of bacterial culture in the center of the plate. The plates were incubated $37^{\circ} \mathrm{C}$ for 24 hours and then observed for the zone of inhibition.

\section{Anti-fungal activities of plant extract of Verbesina encelioides}

Pathogenic plant fungi used were obtained from Department of Pathology, UAS, GKVK, Bangalore. The list of fungi culture was as follows. 


\section{Fungal culture}

F1- Sclerotium rolfsii, F2- Fusarium oxysporum, F3 - Aspergillus flavus, F4 Aspergillus niger and F5-Rhizoctonia solani.

\section{Zone of inhibition test for fungal culture}

The fully-grown fungal plates were taken. With the help of the sterile cork borer $(1.5 \mathrm{~cm}$ in diameter) cut the culture blocks in to cubical blocks. These blocks were then aseptically transferred in to the potato dextrose agar (PDA) plates and incubated for 2 days at $28^{\circ} \mathrm{C}$. Then, all the fungal cultures were grown on both the sides of the culture till paper disc dipped in cell free extract were transferred. The whole set up was incubated at $28^{\circ} \mathrm{C}$ for $2-3$ days and the zone of inhibition was observed.

\section{Results and Discussion}

The plant was surveyed in Eastern dry zones of Karnataka and places like Kolar, Bangalore, Chintamani and Mulabagal. The survey yielded only five strains of the plants from the above regions. Verbesina encelioides plant was characterized biochemically by estimating the total soluble protein, total sugars, phenols and tannin contents.

The total soluble protein estimated results shown that the Strain-3 collected from Kolar district (near Thavarekere village) was found to have higher total protein of $10 \%$, maximum phenol content of $3.6 \mathrm{mg} / \mathrm{g}$, total soluble sugar content of $17.17 \%$ and higher tannin content of $4.72 \%$ compared to all other strains. Strain-3 has recorded maximum zinc content of $60.11 \mu \mathrm{g} / \mathrm{g}$ of dry weight of the plant sample, maximum iron content of $202.17 \mu \mathrm{g} / \mathrm{g}$, manganese content of $120.60 \mu \mathrm{g} /$ $\mathrm{g}$ and copper content of $15.26 \mu \mathrm{g} / \mathrm{g}$ of the dry weight of the plant sample. The results are present in the Table 1.
The standard procedure for the extraction of protein was carried out and total soluble protein banding pattern profile was also done. All strains had similar banding pattern. To determine its inhibition against various bacterial pathogens, bioassays were done. For this zone inhibition assay was carried out. The concentration of protein from Verbesina encelioides used in this study ranges between 5-20 $\mu \mathrm{g}$. The radii of growth inhibition zones were measured in each case after 24 hours. The results indicated the susceptibility of Streptococcus coagulance, Staphylococcus aureus, Enterococcus faecalis, Escherichia coli and Pseudomonas aeruginosa to antibacterial action of protein. E. coli showed better inhibition when compared to other cultures which was followed by E. faecalis, $S$. aureus, $P$. aeruginosa and $S$. coagulance. Similar results were shown by all strains.

Bioassays were done to determine the inhibition of protein against some of the agriculturally important fungal pathogens. For this, zone inhibition assay was carried out (Table 2). The concentration of protein ranges from 5-20 $\mu \mathrm{g}$.

The radii of growth inhibition zones were measured in each case after 48 hours. The results indicated the susceptibility of Aspergillus flavus, Sclerotium rolfsii, Rhizactonia solani, Fusarium oxysporum to anti-fungal action of Verbesina encelioides. Rhizactonia solani and Aspergillus flavus has shown maximum inhibition compared to other cultures. Aspergillus niger showed no inhibition to corresponding concentrations of protein. These results were similar in all the strains. It was an advantage over the other anti-microbial plants as Verbesina encelioides is only effective on fungal plant pathogens. This evidence put together suggest that Verbesina encelioides protein was a moderate anti-fungal protein compared to anti-bacterial activity. 
Table.1 Estimation of various biochemical parameters and micro nutrients content in different strains of Verbesina encelioides

\begin{tabular}{|l|l|c|c|c|c|c|c|c|c|}
\hline Sample & $\begin{array}{l}\text { Place of } \\
\text { collection }\end{array}$ & $\begin{array}{c}\text { Total } \\
\text { soluble } \\
\mathbf{p r o t e i n} \\
(\boldsymbol{\%})\end{array}$ & $\begin{array}{c}\text { Total } \\
\text { soluble } \\
\text { sugars } \\
(\boldsymbol{\%})\end{array}$ & $\begin{array}{c}\text { Total } \\
\mathbf{p h e n o l} \\
\mathbf{c o n t e n t} \\
(\boldsymbol{\%})\end{array}$ & $\begin{array}{c}\text { Total } \\
\text { tannin } \\
\mathbf{c o n t e n t} \\
(\boldsymbol{\%})\end{array}$ & $\begin{array}{c}\text { Zinc } \\
(\boldsymbol{\mu g} / \mathbf{g})\end{array}$ & $\begin{array}{c}\text { Manganese } \\
(\boldsymbol{\mu g} / \mathbf{g})\end{array}$ & $\begin{array}{c}\text { Iron } \\
(\boldsymbol{\mu g} / \mathbf{g})\end{array}$ & $\begin{array}{c}\text { Copper } \\
(\boldsymbol{\mu g} / \mathbf{g})\end{array}$ \\
\hline Strain 1 & $\begin{array}{l}\text { Bangalore } \\
\text { (Marathalli) }\end{array}$ & 5.05 & 7.20 & 0.62 & 2.77 & 41.15 & 74.27 & 121.57 & 9.37 \\
\hline Strain 2 & $\begin{array}{l}\text { Kolar } \\
\text { (Bangarapet) }\end{array}$ & 6.00 & 13.30 & 0.57 & 3.10 & 48.02 & 91.35 & 144.21 & 11.28 \\
\hline Strain 3 & $\begin{array}{l}\text { Kolar } \\
\text { (Thavarekere) }\end{array}$ & 10.00 & 17.17 & 3.60 & 4.72 & 60.11 & 120.60 & 202.17 & 15.26 \\
\hline Strain 4 & $\begin{array}{l}\text { Chintamani } \\
\text { (Hadripura) }\end{array}$ & 5.25 & 6.30 & 0.20 & 2.07 & 58.14 & 103.24 & 180.77 & 10.82 \\
\hline Strain 5 & $\begin{array}{l}\text { Mulbagal } \\
\text { (Pethandalahalli) }\end{array}$ & 5.30 & 15.20 & 1.10 & 3.37 & 55.18 & 78.37 & 165.85 & 8.98 \\
\hline Strain 6 & $\begin{array}{l}\text { Kolar } \\
\text { (Thavarekere) }\end{array}$ & 6.25 & 15.30 & 0.72 & 3.25 & 54.11 & 77.20 & 157.22 & 11.10 \\
\hline
\end{tabular}

Table. 2 Zone of inhibition study of bacterial and fungal pathogens with $14 \mathrm{kDa}$ protein from the medicinal plant Verbesina encelioides

\begin{tabular}{|c|c|c|c|c|c|c|c|}
\hline \multirow{2}{*}{$\begin{array}{l}\text { Sl. } \\
\text { No. }\end{array}$} & \multirow{2}{*}{ Bacterial pathogen } & \multicolumn{6}{|c|}{ 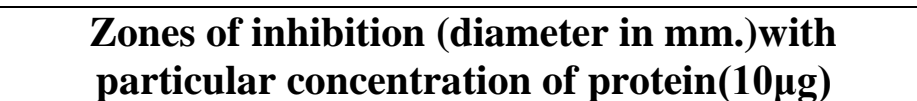 } \\
\hline & & $\begin{array}{c}\text { Strain } \\
1\end{array}$ & $\begin{array}{l}\text { Strain } \\
2\end{array}$ & $\begin{array}{l}\text { Strain } \\
3\end{array}$ & $\begin{array}{l}\text { Strain } \\
4\end{array}$ & $\begin{array}{l}\text { Strain } \\
5\end{array}$ & $\begin{array}{l}\text { Strain } \\
6\end{array}$ \\
\hline 1. & Escherichia coli & 10.0 & 7.0 & 6.0 & 5.0 & 6.0 & 8.0 \\
\hline 2. & Pseudomonas aeroginosa & 9.0 & 8.0 & 7.0 & 6.0 & 5.0 & 8.0 \\
\hline 3. & Staphylococcus aureus & 8.5 & 10.0 & 6.8 & 9.2 & 8.6 & NI \\
\hline 4. & Staphylococcus coagulans & 7.0 & 6.0 & 8.0 & 7.0 & 10.5 & 9.0 \\
\hline 5. & Enterococcus faecalis & 7.5 & 7.4 & 9.0 & 8.0 & 8.6 & 7.6 \\
\hline & Fungal pathogen & & & & & & \\
\hline 1. & Aspergillus niger & NI* & NI & NI & NI & NI & NI \\
\hline 2. & Aspergillus flavus & 7.0 & 7.6 & 9 & 9.0 & 7.0 & 8.0 \\
\hline 3. & Rhizoctonia solani & 7.8 & 6.6 & 7 & 6.0 & 9.0 & 8.0 \\
\hline 4. & Fusarium oxysporum & 7.0 & 8.2 & 6 & 9.0 & 9.0 & 7.6 \\
\hline 5. & Sclerotium rolfsii & NI & NI & NI & NI & NI & NI \\
\hline
\end{tabular}

$*$ NI - No inhibition

Verbesina encelioides is one among the under exploited medicinal plants of Indian origin. The under exploited are to be used to the full extent for unknown medicinal properties. The geographical area of Karnataka is divided in to ten agro-climatic zones. Verbesina encelioides is identified by surveying different dry zones like Bangalore, Kolar, Chintamani and Mulabagal etc. Among the place of collection, the strains collected from Kolar region were found to be more prominent in most of the regions, which were 
identified as Strain - 3 and Strain - 2. These genotypes, which were from different zones, were identified for the strain specificity in different locations. This was done with the help of taxonomist and was confirmed as Verbesina encelioides. The importance of this species was earlier verified for the protein profiling and was found to have both high and low molecular weight proteins. The total soluble protein estimation results shown that Strain-3 collected from Kolar district was found to have higher total protein of $16 \%$ compared to other strains. Bhagat and Jadeja (2003) reported the protein content varied between $10.07-11.96 \%$ in Safed musli accession. Similarly, Dhan et al., (2001) noticed total soluble protein for erect and spreading type of Desmodium gangeticum respectively. There was significant increase in the total soluble sugar content (17.17\%) in the Strain-3 compared to other strains. Similar results were observed in the traditional medicinal plant namely bitter guard, fenugreek and jambu, which varied from 2.03 to 11.765 (Kochhar et al., 2006). There was comparable variation in the total phenol content in the different plant strains.

In Verbesina encelioides maximum total phenol content of $3.60 \%$ was noticed in the Strain-3. Javanmarde et al., (2003) reported similar observation in Basil (Ocimum basilicum). In betel wine fruit pulp, seeds and leaves, Maiti et al., (1999) reported supporting results. Total tannin content recorded in Strain-3 was $4.78 \%$. Similarly Kireeva et al., (1999) observed maximum content of tannin of $16.20 \%$ in Hipericum perforatum, which is measured during intensive vegetative growth. The results of the above experiment revealed that there is difference in the collection of strains. Even though all the plants belong to same genera but seem to be difference in strain. There is strain specificity. This was further verified by other molecular characterization.
Plants unlike humans and animals become sick, but they have evolved a sophisticated defense response against microbes, on a combination of constitutive and inducible response, which can be localized or spread throughout plant organs and tissues. The response is mediated by several messenger molecules that activate pathogen responsive genes coding for enzyme or antimicrobial compounds (Montesinos et al., 2002). Antimicrobial peptides are important biomolecules functioning as self-defense against infection by harmful pathogens. They are isolated from various sources among plants, animals and bacteria and have been characterized (Fugimora et al., 2003). The defense strategy of plants against stress factor involves a multitude of tools, including the synthesis of various types of stress proteins with protective function. A group of plant encoded proteins included by various stress stimuli, pathogenesis related proteins are assigned important role in plant defence against pathogenic infection and in general adaptation to stressful environment.

Conventional control of crop disease depends on the use of chemically synthesized products. However repeated use of such chemicals has several drawbacks, such as their lack of specificity, increased incidence of development of resistance upon prolonged application, and the adverse impact on human health and environment. Genetic engineering of plants by transferring a gene coding for potent anti-microbial protein has now been accepted as a method of choice for directional improvement and development of disease resistant plants (Moreno et al., 2005). Taking into consideration the potential of antimicrobial proteins in plant protection strategies, the relevance of this study can be very well understood.

Young leaves of Verbesina encelioides were used for extraction of anti-microbial protein. 
In many reports, more anti-microbial activity has been found in young leaves as compared to old ones. Further it has been shown that some of the PR proteins are expressed in tissue specific manner during the development (Bol et al., 1990). Hegaard et al., (1992) reported several fold increase in the synthesis and extra cellular accumulation by barley leaf protein in response to Erysiphae infection. Three distinct basic 14k Da proteins p14a, p14b, and p14c were isolated from tomato (Lycopersicum esculentum Mill cv. Baby) leaves infected with phytophthora infestance both In vitro and with bioassay carried out with tomato leaf discs (Niderman et al., 1995).

Zone inhibition assay was carried out for the determination of antibacterial and antifungal activity. Antibacterial activity of protein revealed that Pseudomonas aeruginosa showed minimum inhibition when compared to other cultures. Enterococcus faecalis was found to be maximum effective to corresponding concentrations of protein. Similar results were observed Verbesina encelioides extract, which was most effective against Staphylococcus aureus, Bacillus cereus and Vibrio cholera, whereas it was not much effective against Shiegella dysentriae and Salmonella typhi (Nickavar and Mojab, 2003).

Antifungal action of protein revealed that Aspergillus flavus and Fusarium oxysporum showed maximum inhibition as compared to other fungal pathogens where as Aspergillus niger and Sclerotonia rolfsii showed no inhibition. Similar results were recorded by Mahasner (2002) in Avecennea marina, which aqueous extract exhibited moderate antifungal activity against Aspergillus flavus and Candida albicans. Based on results it implies Verbesina encelioides is a very potential antibacterial agent, which may act on broad range of phytopathogens, and it is a moderate anti- fungal agent, which act on few phytopathogenic fungi. Cloning and expression of Verbesina encelioides antimicrobial protein gene will be of great importance in agriculture for developing transgenic plants resistant to wider range of fungal phytopathogens. The result of the protein helps to characterize genotypes collected from different localities. Further the bands have to be still analysed. For the other characters, this protein profiling in the exotic medicinal plant was done for the first time and the other molecular characterization results are awaited.

\section{References}

Bhagat, C. and Jadeja, G.C. 2003. Variation and correlation in root yield and biochemical traits of Safed musli (Chlorophytum borivilianum). J. Med. Aromatic Plant Sci., 25: 33-36.

Black, C.A. 1965. Method of soil analysis American Agronomy Inc., Madison, Wisconsin, USA. pp.131-137.

Bol, J.F., Linthorst, H.J.M. and Cornelissen, B.J.C. 1990. Plant pathogenesis-related proteins induced by virus infection. Ann. Rev. Phytopathol., 28: 113-138.

Burns, R.E. 1971. Method for estimation of tannin in grain sorghum. Agron.J.63: 511.

Dhan, P., Niranjan, A. and Tewari, S.K. 2001. Chemistry of Desmodium gangeticum cultivated on sodic soil. J. Med. Aron. Pl. Sci., 21(4A): 21-25.

Dubois, M., Gilles, K., Hammiltron, J.K., Robers, P.A. and Smith, F. 1951. A colorimetric method for the determination of sugars. Nature, 168: 167-168.

Fujimora, M., Minami, Y., Watanable, K. and Tadera, K. 2003. Purification characterization and sequencing of a novel type antimicrobial peptides, Fa-AMP1 and Fa-AMP2, from seeds of Buckwheat (Fagopyrum ecculentum Moench.) Biotechnol. Biochem., 67(8): 1636-1642.

Hejgaard, J., Jacobsen, S., Svendsen, I. 1991. Two antifiingal thaumatin-like proteins from barley grain. FEBS Lett., 291: 127-131. 
Javanmarde, J., Stushnoff, C., Locke, E. Vivanco, J.M. 2003. Antioxidant activity and total phenolic content of Iranian Ocimum occessions. J. Food Chemist., 83: 547-550.

Kireeva, T.B., Sharanov, U.L. and Letchamo. W. 1999. Biochemical and Eco physiological studies on Hypericum sp. Int. J. Janick (ed.). 467-468.

Kochhar, A., Nagi, M. and Sachdeva, R. 2006. Proximate composition, available carbohydrates, dietary fibre and anti nutritional factors of selected traditional medicinal plants. J. Human Ecol., 19(3): 195-199.

Laemmli, U.K. 1970. Cleavage of structural proteins during the assembly of the head of bacteriophage T4. Nature, 227: 680-685.

Lowry, O.H., Rosenbrough, N.J., Farr, A.L. and Randall, R.J. 1951. Protein measurement with the Folin Phenol reagent. J. Biol. Chem., 193: 265-275.

Mahasner, A. M. 2002. Screening of some indigenous Qatari medicinal plants for antimicrobial activity. Phytotherapy-Res., 16(8): 751-753.

Maiti, S., Kumar, N., Shivashankar, K.S., Pandey, S., Mishra, S.K. and Mithila, J. 1999. Biochemical constituents of fruits and seeds of betel vine (Piper beetle). J. Med. Aromatic Pl. Sci., 21: 654-657.

Malik, E.P. and Singh, M.B. 1980. Plant Enzymology and Hittoenzymology $\left(1^{\text {st }}\right.$ Edn.) Kalyani Publishers: New Delhi; 286

Montessions, E., Bonaterra. A., Badora, E., Frances, J., Alemany, J., Llorente, I. and Moragrega, C. 2002. Plant-microbe interactions and the new biotechnological methods of plant disease control. Int. Microbiol., 5: 169-175.

Moreno, A.B., Rufat, G.P.M., Bravo, J.M., Estopa, M., Messeguer, J. and Segundo, B.S. 2005. Pathogen-induced production of the antifungal AFP Protein from Aspergillus giganteus confers resistance to the blast Fungus Magnaporthe grisea in transgenic rice. Mol. Plant Microbe Interact., 18(9): 960-972.

Nickavar, B., Mojab, F. 2003. Antibacterial activity of Pulicaria dysentrica extracts. Fitoterapia, 74(4): 390-393.

Niderman, T., Bruyère, T., Giigler, K. and Mosinger, E. 1993. Antifungal activity of native and recombinant tomato $\mathrm{P} 14$ proteins. In B Fritig, M Legrand, eds, Mechanisms of Plant Defense Responses. Kluwer Academic Publishers, Dordrecht, The Netherlands, p- 450

Niderman, T., Genetet, I., Bruyere, T., Gees, R., Stintzi, A., Legrand, M., Fritig, B. and Mosinger, E. 1995. Pathogenesis-related PR-1 proteins are antifungal. Isolation and characterization of three 14-kilodalton proteins of tomato and of a basic PR-1 of tobacco with inhibitory activity against Phytophthora infestans. Plant Physiol., 108: 17-27.

Parker, A.S.B. 1972. Classification and identification of Staphylococci and their resistance to physical agents. Wiley, New York.

Robbins, Bellue, M.K. and Ball, W.S., 1951. Weeds of California. State Printing Division.

\section{How to cite this article:}

Divya Ramakrishnan, C.K., Dayal Doss and Vijayabharathi, A. 2017. Biochemical and Antimicrobial Characterization of an Underexploited Medicinal Plant - Verbesina encelioides. Int.J.Curr.Microbiol.App.Sci. 6(12): 3407-3416. doi: https://doi.org/10.20546/ijcmas.2017.612.396 